\section{Osmanlılarda Şeker Üretimi ve Tüketimi}

DOI 10.32325/iaad.2019.23

Türkler Osmanlı döneminden çok önce şekeri biliyordu. 7. yüzyılda Orta Asya'da yolculuk eden Çinli Hiüen-Tsang'a, Göktürk hükümdarı Tong Yabgu tarafından çağrıldığı bir ziyafette bir tür sert şeker ikram edilmiştir. 11. yüzyılda Karahanlı Yusuf Has Hacib, varlıklı insanların şeker yediklerini anlatır ve Kaşgarlı Mahmud şeker konulan iki tür tatlidan bahseder: “Külde pişirilip yağ içine doğranan ekmektir, üzerine şeker dökülür" olarak tanımlanan isberi ve bir tür sütlaç olan $u w a$. Bu şeker ya Hindistan ya da İran'ın Huzistan bölgesinde üretilen kamışs şekeriydi.

6. yüzyılda İranlılar şeker işleme teknolojisini ileriye götürmüşler. 7. yüzyılda İran'ı fetheden Araplar, şeker kamışı tarımı ve şeker üretimini Akdeniz bölgesine yayınca, Suriye ve Mısır en önemli şeker üretilen bölgeler haline geldi. Anadolu'da da, 13. yüzyılda Selçuklu döneminde, Mevlana eserlerinde birçok kez şekerden bahseder: "Şeker kamışından bir yolunu bulurlar, şeker çıkarırlar, şeker yaparlar."

Osmanlı kültüründe şeker, bir tattan çok öte anlamlar kazanmış, sevgi, güzellik ve iyi niyetin sembolü olmuştur. 15 . yüzyılda kayda geçen "Dili ağzında şeker olsun" deyimi, bu durumu yansitır. 14. ve 15. yüzyıllarda divan şairleri, gül reçelinin hastalara götürüldüğünü, şekerleme ve şekerli şerbetlerin misafirlere ikram edildiğini anlatıyor. 16. yüzyıldan itibaren toplumda şekerle ilgili gelenekler çoğalmıştır. 17. yüzyılda şair Nedîm, kahvenin yanında gül reçeli verildiği ve bayramda ikram edildiğini anlatır. İlk kez 16. yüzyılda ortaya çıkan akide şekeri, düğünler, Ramazan bayramları, kandiller gibi özel günlerin vazgeçilmez ikramı olmuştur. Bunun sonucu olarak talep öyle artmıştır ki, kaçak şekerciler ortaya çıkmış, şeker fiyatları fırlamış ve 1582 'de kaçak şekerciliği yasaklayan bir ferman çıkarılmıştır. Ramazan Bayramı için "Şeker Bayramı" adının kullanılmasına ilk kez 18. yüzyılda bir arşiv belgesinde rastlandığına göre, bu kullanım halk arasında uzun süre önce benimsenmiş olmalıdır.

Erken Osmanlı döneminden itibaren saray ve zengin çevrelerde şekerlemeler, şekerli yiyecekler ve şerbetler, bayram ve düğün gibi kutlamalarda mutlaka ikram ediliyordu. 1382 yılında Sultan I. Murad'ın oğlu Bayezid, Germiyan Beyi'nin kızı ile evlenince, düğünde bol miktarda şekerleme dağıtılmıştır. Fatih Sultan Mehmed'in oğullarının 1456 yılında yapılan sünnet düğünü için şekerlemelerden başka renkli şekerden kale, cami, köşk ve bahçe modelleri yapılmıştır. Bu dönemin şiirlerinde badem şekeri ve leblebi şekerinin adları geçmektedir.

Misır'in 1517 yilında Osmanlılar tarafından fethedilmesiyle şeker bollaşınca, tarihçi ve şair Gelibolulu Mustafa Âlî, M1sır'ın şekerini bir denize benzetti. Ayrıca Suriye de önemli bir şeker sanayiine sahipti. Alman bilgin Dr. Leonhart Rauwolff, 1573 yılında ziyaret ettiği Trablusşam'da şeker kamışının bu bölgede bolca yetiştirildiğini ve bundan büyük miktarlarda kelle şekerin üretildiğini kaydetmiştir.

Osmanlı sarayında şeker tüketimi gittikçe artmış; 15. yüzyıl sonlarında yılda beş tonken, 16. yüzyılda 35 tona, 17. yüzyıl ortalarına doğru ise 65 tona yükselmiştir. Pahalı olduğu için saray çevreleri ve zenginler dışındaki insanlar ancak özel günlerde şeker tüketebiliyorlardı. Şeker, uzaktan taşınması, yüksek talep ve 15. yüzyılın sonundan itibaren gümrük vergisi alınmasından dolayı pahalıydı. 16. yüzyılda şekerin fiyatı balın neredeyse iki misliydi. 17. yüzyılda ise iyi şekerin fiyatı üç misline firladi.

Şekli ve saflık derecesine göre şekerin birçok çeşidi biliniyordu. 15. yüzyılın başında yazılan Türkçe tıp kitaplarında 
adı geçen şeker çeşitleri arasında parmak şekeri, kelle şeker, ak şeker, kızıl şeker (esmer şeker), nöbet şekeri ve peynir şekeri bulunmaktadir.

Reçel, tatlı ve şerbet için her zaman beyaz şeker tercih edilmiştir çünkü esmer şeker, bal ve pekmez, bunların renklerini bozdukları gibi tatlarını da etkiler. Bundan dolayı 16. yüzyıla ait bir baklava tarifinde "karınca başı nöbet şekeri, bulunmaz ise beyaz Mısır şekeri" kullanması gerektiğine dair bir talimata rastlanır. 17. yüzyılda yemeğe düşkün Erzurum Paşası Defterdar Mehmed Paşa, mutfağına bal ve esmer şeker sokmaz, bütün tatlılarında sadece Şam'ın beyaz şekerini kullanırdı.

Üç kez rafine edilen beyaz şeker, genellikle koni şeklinde kalıplarda hazırland1ğından buna kelle şeker denirdi. Bu şeker sert olduğundan özel bir çekiçle kırılırdı. Refik Halid Karay (1888-1965), çocukluk anıları arasında kelle şekerin parçalanmasını seyrettiğini anlatır: “O zamanlarda şekerler kelle, daha doğrusu mahrutî şekilde satıldığından yine boy boy, evlerde kırılır, öyle saklanırdı. Evlerde çekiçle şeker kırılışı eğlenceli olduğundan bugünleri kaçırmaz, genç hizmetçilerin [...] yüzlerine toplanan şeker tozlarını seyretmekten hoşlanırdım."

İri kristaller halinde çok saf bir şeker türü olan "nebat şekeri", halk ağzında bozularak Türkçede "nöbet şekeri" şeklini almıştır. Nöbet şekeri yapımında kullanılan özel kazanların duvarlarında delikler bulunur, bunlardan geçirilen birçok ip yatay olarak gerdirilir. Deliklerden şurubun sızmasını önlemek için kazanın dışına alçı sürülür, sonra içine şeker şurubu dökülür ve çuvala sarılarak 1 lık bir yerde bir hafta bırakılır. Açıldığında iplerde büyük şeffaf kristallerin oluştuğu görülür.

Peynir şekeri, beyazlaşıncaya kadar çekilen şeker ağdasından hazırlanan, ufak lokma veya çubuk şeklinde bir şekerlemedir. Bir kaç gün durduktan sonra tebeşir kıvamını aldığından dolayı buna Türkçede "peynir şekeri" adı verilmiştir.
Frenk şekeri, Avrupa ülkelerinin Amerika'daki sömürgelerinde ürettikleri, kelle şeklinde beyaz şekerdi. 18. yüzyıldan itibaren Osmanlı piyasasında bu şeker bulunuyordu fakat Misır şekeri daha ucuz ve iddia edildiğine göre daha tatlı olduğundan halk tarafından tercih ediliyordu.

Evliya Çelebi, 17. yüzyılın ilk yarısında yazdığ 1 Seyahatnâme'sinin ilk cildinde, Mısır'n şekeri yerine bal tüketilmesi, hatta Misır yerine Suriye ve Anadolu'da şeker üretimine başlanması gerektiğini savunmuştur: "Padişah istese Alanya, Antalya, Silifke, Tarsus, Adana, Payas, Antakya, Halep, Şam, Sayda, Beyrut ve Trablusşam'da yüz binlerce kantar şeker olur ki cihanı doyurur" diye yazan Evliya Çelebi, 370 yıl önce Anadolu'da şeker sanayii kurma fikrini ortaya atan ilk kişi olmuştur.

\section{Priscilla Mary Işın}

